\title{
Drip Fertigation in Pulses - A Novel Approach to Boon the Yield
}

\author{
M Uma Maheswari* \\ Department of Agronomy, India

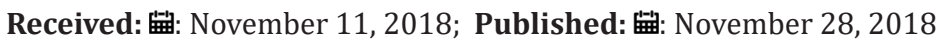 \\ *Corresponding author: M Uma Maheswari, Department of Agronomy, India
}

\section{Introduction}

In near future, several developing countries would face major challenge in achieving sustainable food security. For enhancing sustainable food production, proper and effective use of available land, water and fertilizer resources are essential. This requires agricultural intensification with the emerging concept of fertigation, scientific usage of micro-irrigation with water-soluble fertilizers and prevention of soil pollution and restoration of soil health. The yield and quality of the produce is mainly depending upon the agronomic practices, mainly nutrient and water management. Under the present situation, cultural methods are need to be modified and standardized based on the need of existing market and immediate attention has to be given for maximizing the productivity of crops. This is possible through application of adequate quantity of the available water and fertilizers economically as and when required. Solaimalai et al. [1] considered drip irrigation is one of hi-tech method which receives wider acceptance and adoptability, particularly in areas of water is scarce. Hence, it is very important that the concerted efforts are now needed to harness the available quantities of water for achieving higher productivity per drop of available water. Fertigation is a practice, through which fertilizers are applied along with irrigation water through drip system. The crop yields are increased due to higher fertilizer use efficiency as the fertilizers are applied through drip system.

Pulses are mostly grown under rainfed situation. Due to the uneven distribution of rainfall, the crop is not able to get required amount of water during the critical stages of their life cycle. Drip fertigation is the best option available for pulses to increase productivity with less quantity of water and judicious use of fertilizer input. The adoption of drip fertigation technology is highly successful in the case of commercial crops such as banana and sugarcane. While the pulses are generally cultivated under rainfed or rice fallow situations, the concept of drip fertigation could be well exploited under irrigated condition to increase pulses productivity and also to save total water requirements. To improve the pulses productivity through intensification process, growing pulses under irrigated condition along with drip fertigation is essential. These facilitate us to reduce the gap between production and requirement. Among the different agricultural techniques, drip fertigation is the most effective method for enhancing the use efficiency of two key inputs namely water and nutrients. Hence, the importance of fertigation in pulses is discussed in detail for better understanding as well as to increase the area and production

\section{Water Requirement}

Water is a key input to attain desired growth and yield of any crop. Water needed for normal growth, development and yield of crop may be supplied through precipitation or by irrigation or by both. As reported by Saxena et al. [2], pulse crop uses around 200-250 mm water to produce one-ton grain ha-1. Agarwal et al. [3] reported that the consumptive use of kharif pigeon pea was estimated as $406 \mathrm{~mm}$ at Hisar, $416 \mathrm{~mm}$ at Sriganganagar and $491 \mathrm{~mm}$ at Pantnagar. Tomar et al. [4] noted that seed yield of pigeonpea was higher in scheduling of irrigation at IW/CPE ratio of 0.5 at branching, flowering and pod development stages over two irrigations at branching and pod development stages. Gajera et al. [5] stated that the irrigation could be scheduled by adopting IW/CPE ratio of 0.30 for the maximum production of pigeonpea. The seed yield of pigeonpea (16.51 q ha-1) was significantly higher with two protective irrigations than one protective irrigation (14.33 q ha-1) and control (10.96 q ha-1). Duraisamy et al. [6,7] reported that the irrigation scheduled at IW/CPE ratio of 0.45 showed the highest water use efficiency of $1.05 \mathrm{~kg}$ ha- $1 \mathrm{~mm}-1$ as compared to other treatments was observed in perennial pigeonpea (BSR 1). Irrigation at every 14 days from flower initiation to pod development stage of pigeonpea was optimum for producing ample quantity seeds Mula 
et al. [8]. The highest seed and stalk yield (1429 kg ha-1 and 3921 $\mathrm{kg}$ ha-1 respectively) was recorded in pigeonpea by scheduling irrigation at IW/CPE ratio of 0.9 Thanki et al. [9].

\section{Effect of Crop Water Stress on Growth and Productivity}

In semi-arid regions, pigeonpea is often subjected to terminal water deficit during flowering and pod filling phases. Water stress is responsible for rapid leaf shedding, reduction in grain size, weight and grain yield of crops Becker et al. [10]. Water deficit may also affect the canopy development through its effect on total leaf number Arkin et al. [11]. The leaf area decreased with the proportional increase in water stress. The quantity of total chlorophyll has been found to be affected by short supply of water, irrespective of the plant parts viz. leaves, flowers and pods. Chlorophyll 'a' has been affected to a greater extent than chlorophyll 'b' content. Stress induced decline in protein content has been correlated with increased protease activity in plants De Lucad'Oro $[12,13]$ in a pot culture study with pigeonpea with three moisture regimes found a sharp reduction in growth parameters and maximum leaf shedding under severe water stress condition. Porter et al. [14] observed that plant morphology, biomass production and root diameters were significantly affected by moisture regimes. They also reported that plants which were frequently supplemented with water were found to grow taller with more number of leaves, accumulated maximum dry weight and had larger diameter vessels within the root tissue of pigeonpea.

\section{Micro Irrigation}

Among the different sector, agricultural sector consume the largest portion of water for various operations. The flood irrigation system is the major practice followed for irrigation and the efficiency ranged between 25 and 40 per cent. Food production in India needs to be doubled to feed the projected population by 2020 so as to meet the food security. Adoption of micro irrigation for pulse crop may help in saving significant amounts of water in dry areas and increase the quality and quantity of produce. As the new slogan "more crop per drop of water" is in force, emphasize need to be given for water conservation and improvement in wateruse efficiency. Micro irrigation is one of the irrigation methods and has several manifold advantages over the conventional irrigation practice. Micro irrigation can reduce the wastage of water to a negligible amount results in increasing irrigation use efficiency in pulses. Micro irrigation precisely supplies water and nutrients to the plants in time to avoid plant stress. It also optimize pulse production (maximize economic yield for each unit of water) and increase the quality of end products. Micro irrigation has many potential advantages like increased beneficial use of water, enhanced plant growth and yield, efficiency of fertilizer and other chemicals, reduced salinity hazard, limited weed growth, decreased energy requirements and improved cultural practices [15-17] indicated that through micro irrigation the problem of soil salinity and degradation, poor crop yield could be prevented by applying water to the effective root zone under low pressures. Considerable water saving up to 50 per cent was possible through micro irrigation by maintaining available soil moisture at low water tension and almost constant during entire growth period of crop Patel et al. [18].

\section{Drip Irrigation}

Drip irrigation is method of irrigation to provide water most efficiently and precisely near the root zone of the crop. Drip irrigation can be mostly practiced for growing vegetable crops with considerable savings in irrigation water. Drip irrigation is now being used in row crops such as cabbage, potato, cassava, etc., in water deficit areas. Ahluwalia et al. [19] reported that considerable saving of irrigation water can be achieved by adopting drip method, as water applied almost precisely and directly to the root zone. For installing the drip irrigation economically in row crops like tomato, potato, etc., paired row planting method can be adopted without reduction in plant population for considerably reducing the cost of laterals and also to economize irrigation water without any reduction in the recommended optimum plant population.

In drip irrigation system, generally between 15 to 60 per cent fraction of the soil surface is wetted. During initial period of establishment, drip irrigation was considered as an emerging technology with its application limited to some special crops. At present, drip system is being practiced on a wide variety of crops, which was initially considered uneconomical Nakayama et al. $[17,20]$ stated that the use of drip irrigation along with fertigation saves water and fertilizer results in better yield and quality of pulse crop. The benefits of drip irrigation include better crop survival, reduce water usage, higher yield and improved crop quality Martin et al. [21]. Increase in crop yield, quality and reduction of leaching loss of nutrients below the rooting zone could be achieved by using drip irrigation Hagin et al. [22]. Drip irrigation has the potential for improving most common contributing factors for the growth of crops such as over fertilization and over irrigation. Irrigation requirement can be reduced by 50 to 80 per cent with drip irrigation compared to conventional irrigation and sprinkler irrigation Locascio et al. [23]. Significantly higher fruit yield of tomato was obtained from drip irrigated plots and the increase was 40.4 per cent than the surface irrigation Bafna et al. [24]. Drip irrigation has proved its superiority over other methods of irrigation owing to direct application of water in the root zone of crops. Drip irrigation can play a vital role in increasing water use efficiency with economically feasible in high value crops $[1,25]$ reported that the increase in seed cotton yield under drip irrigation was 24, 35, 45 and 53 per cent over all furrow, skip furrow, alternate furrow and check basin method, respectively.

\section{Effect of Drip Irrigation on Growth Parameters of Crops}

Anil Kumar (2005) reported that drip irrigation significantly increased growth parameters like number of leaves and dry matter production in baby corn at 100 per cent PE over 75 per cent PE, 50per cent PE and surface irrigation. The highest dry matter production of cotton was recorded in drip irrigation as compared to surface irrigation Sampathkumar et al. [25,26]. Similarly, drip irrigation recorded higher dry matter production in tomato over furrow irrigation Hebbar et al. [24,27] stated that drip irrigation 
with 100 per cent Epan recorded the higher plant height (177.3, $169.0 \mathrm{~cm})$, ear length $(19.97,19.03 \mathrm{~cm})$ and single fresh ear weight of corn $(255.3,243.7 \mathrm{~g})$ whereas, the lowest values were found at 70 per cent Epan. Gupta et al. [28] noted that drip irrigation along with fertigation was found superior than their individual effects. The treatment combination of 80 per cent ET through drip and 80 per cent recommended NPK through fertigation recorded maximum fruit yield in chillies (366.48 q ha-1). Pigeonpea grown under drip irrigation with 0.8 Epan during the crop period recorded higher plant height $(61.6 \mathrm{~cm})$, LAI (2.04) and total dry matter production (3731 kg ha-1) at harvest.

\section{Effect of Drip Irrigation on Yield of Crops}

Vishwanatha et al. [25] recorded maximum grain and stover yields by drip irrigation at 0.8 Epan under normal planting (200.7 and 248.7 q ha-1, respectively) over 0.4 and 0.6 Epan by drip (159.3, 202.3 and 167.0, 214.0 q ha-1, respectively) in sweet corn in red sandy loam soil. Yazar et al. [29] recorded higher corn yield of $11920 \mathrm{~kg}$ ha- 1 from the full irrigation treatment (100 per cent CPE) with six days interval. Based on the results, trickle irrigation system could be used successfully for irrigation of corn crop under arid climatic condition. Around 371 to $428 \mathrm{~mm}$ of water was used under drip irrigation, while it was 547 to $629 \mathrm{~mm}$ of water under furrow irrigation system $[30,31]$ reported that among the different irrigation schedules, drip irrigation at 100 per cent PE recorded higher yield and other parameters like baby corn length, girth and number of cobs per plant over drip irrigation at 75 per cent PE, 50 per cent PE and surface irrigation. Rani et al. [32] observed that drip irrigation at 80 per cent pan evaporation and 50 per cent fertigation of recommended dose of $\mathrm{N}$ and $\mathrm{K}$ as the best agronomic practice to have higher yield of baby corn. Abdullah Oktem [27] recorded highest fresh ear yields (14.76 and $14.17 \mathrm{t}$ ha-1) at 100 per cent $\mathrm{E}$ pan, whereas lower fresh ear yields (9.15 and $8.84 \mathrm{t}$ ha-1) were observed at 70 per cent of $E$ pan during the year 1998 and 1999 respectively. In pigeonpea, highest seed yield of $33 \mathrm{q}$ ha-1 was recorded in farmer's field by adopting drip irrigation in Hingne village of Jalgaon district in Maharashtra [33,34] observed that grain yield of maize was significantly higher (7.46 t ha-1) in fertigation scheduled at 1.0 Epan and 100 per cent RDF with water soluble fertilizers like MAP, urea and KNO3 over fertigation at 1.0 Epan with 100 per cent RDF through conventional fertilizers application. Mahalakshmi et al. [35] reported that drip irrigation with $0.8 \mathrm{E}$ pan throughout the crop period of pigeonpea recorded the higher grain yield of $3731 \mathrm{~kg}$ ha-1.

\section{Effect of Drip Irrigation on Quality Components of Crops}

Malik et al. [36] found that under drip irrigation, maximum yield (296.9 q ha-1), fruit size $(61.7 \mathrm{~mm})$ and TSS (5.6 per cent) were recorded in tomato when recommended fertilizer $N$ (200 kg ha-1) was applied through drip irrigation. Except for diameter and weight, quality parameters of cauliflower were generally not affected by $\mathrm{N}$ or irrigation treatments, except in the control plots Thompson et al. $[37,38]$ reported that two row planting under drip irrigation with 100 per cent Epan had higher juice weight than the surface irrigation method over all other methods of planting in sugarcane. Manish Kumar et al. [39] noticed that scheduling of irrigation at 1.0 IW/CPE ratio recorded the lowest protein content in grain $(9.87 \%)$ over one irrigation at tasseling at $0.7 \mathrm{IW} / \mathrm{CPE}$ ratio (10.41\%) in sandy loam soil of Raipur during 1997. Sunder Singh et al. [40] revealed higher crude protein (13.23\%) and vitamin C (12.65 mg $100 \mathrm{~g}$-1) due to irrigation at $1.0 \mathrm{IW} / \mathrm{CPE}$ ratio over 0.75 and $0.5 \mathrm{IW} / \mathrm{CPE}$ ratio (12.78 and 12.57, and 12.11 and 12.44 respectively) in sandy clay loam during summer 1997 at Coimbatore. Thus, increasing the irrigation regimes improves the quality characters of crops.

\section{Moisture Distribution Under Drip Irrigation}

Water movement and its distribution under drip irrigation in the soil mainly depends upon many parameters like type of soils, infiltration rate, hydraulic conductivity of the soil, emitter discharge rate, quantity of irrigation water to be applied, soil moisture content, depth of water table and few climatic factors. Moisture distribution pattern in drip irrigation is mainly depends upon the rate of application of water and soil profile. Higher rate of application may lead to deep percolation loss whereas; a very low rate may result in evaporation losses. The size of the wetted soil surface and geometry of the wetted zone is decided by irrigation frequency and rate of water application in drip irrigation system. The wetted soil surface influences the extent of the evaporating surface and the geometry of wetted zone determines the zone of root activities and the efficiency of the particular regime. Moisture distribution pattern of summer squash irrigated under drip for the daily irrigation treatment shows that downward water movement is limited to surface $60 \mathrm{~cm}$ while lateral movement occurs up to $60 \mathrm{~cm}$ from the emitter Earl et al. [41,42] observed the water movement pattern for a discharge rate of 8lph and noted that it was moved in both horizontal and vertical directions upto $30-40 \mathrm{~cm}$ distance. For discharge rate of $4 \mathrm{lph}$, the moisture content after 48 hours at the surface (below the emitter) was decreased from 37.8 to 27.8 per cent. The moisture content after 48 hours at $30 \mathrm{~cm}$ depth below the dripper was found to be stabilized at 23.9 per cent in $0-30 \mathrm{~cm}$ depth. Discharge rate of $4 \mathrm{lph}$, the moisture content for $40 \mathrm{~cm}$ distance away from the dripper was 21.8-22.7 per cent. The water applied at higher rate saturated the soil near the dripper and infiltration rate was slower, whereas the water percolated deeper with lower application rate as more time was available for infiltration Goel et al. [43]. Contrary to this result, Khepar et al. [44] noted that deeper penetration in the soil profile observed at higher discharge rates.

Soil moisture content after 6 hours irrigation was the maximum in 30-45 cm depth interval at all points along the radial distance between two emitters. Further, the moisture content at a radial distance of $30 \mathrm{~cm}$ was the lowest from a given emitter at all soil depths. However, the moisture content was increased with decreasing radial distance from the emitter with maximum value obtained at the point source Ahluwalia et al. [19]. The soil water content (by volume) distribution in the profiles was higher near the emitter and decreased as the distance from the emitting point increased under all drip and fertigation treatments. This difference 
however, was not observed below $30 \mathrm{~cm}$ depth, irrespective of the distance from the emitter Debashis Chakraborty et al. [45] noted that frequent irrigations under drip irrigation system had maintained soil moisture content that did not fluctuate between wet and dry extremes and also most of the soil in the root zone was kept in well aerated condition. He also observed that the water movement in the soil depends on characteristics of the soil and dripper discharge rate. Faster wetting front movement in both radial and vertical directions was observed at higher application rate. The wetted depth was significantly increased with volume, but horizontal wetted area was not affected.

This may be due to the water entry into saturated radius approaching a constant value at particular time. Li et al. [46] reported that water distribution in horizontal direction is more when water application rate is increased, while decreasing the rate allows more water to distribute in vertical direction. The wetted zone geometry was affected by soil type, the volume of water applied to the soil and emitter discharge rate Amin et al. $[47,48]$ also stated that under drip irrigation system, available soil moisture was almost consistent and nearer to field capacity as against wide fluctuation under surface irrigation. Adequate soil moisture availability ensures successful cotton production under any type of cultivation. Higher available soil moisture (ASM) was observed in drip irrigation plots as compared to furrow irrigation in two soil depths of $0-15 \mathrm{~cm}$ and $15-30 \mathrm{~cm}$ Veeraputhiran et al. [49]. reported increased available soil moisture with increase in irrigation from 0.5 to 1.0 ETc. In 1.0 ETc, soil moisture content remained very near to field capacity of $115 \mathrm{~mm}$ per $60 \mathrm{~cm}$ soil layer. However, irrigation up to $0.80 \mathrm{ETc}$ also seems to be adequate as soil moisture depletion was found within the range of 25 per cent of 86 $\mathrm{mm}$ per $60 \mathrm{~cm}$ of available water but drip irrigation at $0.7 \mathrm{ETc}$, soil moisture depletion beyond 25 per cent available water. At higher deficit irrigation level of $0.6 \mathrm{ETc}$ to $0.5 \mathrm{ETc}$, soil moisture availability to the crop was inadequate for its full growth in fine loamy soil with 4lph dripper. Prashant Shrivastava et al. [50] reported that the lateral and vertical spread of water in the soil increased with the amount of irrigation.

\section{Rooting Pattern Under Drip Irrigation}

In order to achieve proper growth, the root zone of a plant must be well supplied with both water and oxygen. Water potential should be kept close to saturation Stanhill et al. [51] but, if a low water tension is maintained in a clay soil, plants will suffer most of the time from a sub-optimal level of oxygen supply in the root zone Follett et al. [52,53]. Oxygen is essential for good root development. If oxygen percentage is reduced, root growth ceases altogether and ultimately there will be no recovery of normal root growth even roots are well supplied again with oxygen Brandt et al. [54,55]. The trickle irrigation synonymous to drip irrigation is a modern technique which is supposed to solve this problem. The water spreads from the trickler according to the potential gradients in a three-dimensional flow and creates a pear shaped mass of wetted soil Goldberg et al. $[56,57]$. Therefore, the soil is saturated only in the vicinity of the trickle, while most of its volume is wetted by an unsaturated flow. These features of drip irrigation system enable frequent water applications in small amounts, which maintain the moisture regime in soil volume quite stable.

In drip irrigation system the root development is restricted to the soil volume wetted by the emitters near the soil surface and root length and density was decreasing with depth Stevens et al. [58]. Most of the roots are present in the top of the soil i.e 75 per cent of roots occurring within $50 \mathrm{~cm}$ of the emitter, around the water source for daily irrigated plots. In contrast, under weekly irrigated plots roots are more evenly distributed laterally with 63 per cent occurring within $50 \mathrm{~cm}$ of the emitter. In case of root length, roots are highly concentrated in the surface layers in the daily irrigated plots, with 64 per cent occurring in the upper 45 $\mathrm{cm}$ and the density markedly decreasing below $75 \mathrm{~cm}$. In weekly irrigated plots, roots are more evenly distributed with 43 per cent in the surface $45 \mathrm{~cm}$ and root penetration up to below $120 \mathrm{~cm}$ was observed Earl, [41]. In trickle irrigated wheat crop, roots tend to accumulate in the margins of the wetted zone in and no root growth occurred beyond a distance of $35 \mathrm{~cm}$. This was due to limited wetted area of the lateral distance. The results concluded that irrigation from through trickler may solve the problem of the root system for a low water tension on the one hand and good aeration on the other hand Silberbush et al. [56,59] reported that root water uptake is not always in direct proportion to root length density. In response to irrigation water distribution, plants can quickly adapt to spatial pattern of water uptake Clothier et al. [60]. To match irrigation system design and management with crop requirements, information about the structure and function of crop root systems is essential. Through root weight density or root length density (RLD) rooting pattern of the crop can be traditionally analyzed. The main indicator of potential water uptake is distribution of root length density Sharp et al. [61]. The actual water uptake patterns (root activity or effectiveness) reflect a complex system between root length density and other factors like water, nutrient and aeration status of the root zone. It is a need of hour for better understanding of crop root distributions and water uptake patterns, as we seek to develop modern and environmental friendly practices involving high frequency irrigation and fertigation for higher production Clothier et al. [60]. Evidence shows that root systems under partial soil wetting are dominated by the wetting pattern under the drippers Clausnitzer et al. [62]. The tomato root length intensity decreased as water applied decreased and the pattern of root distribution along the soil profile shows an exponential decrease in root length intensity with depth. The larger proportions of roots were found in the area of the emitter, close to the plant and decreases with distance from the emitter.

Between 12 and 21 per cent of total root length was found more than $0.5 \mathrm{~m}$ from the stem, which can be attributed to interpenetration of roots from plants of adjoining rows Oliveira et al. $[63,64]$. reported that the root length of chilli was higher when irrigation was scheduled at $83 \mathrm{~mm} \mathrm{CPE}$ as compared to irrigation at 63 and $53 \mathrm{~mm}$ CPE reported that root length and root dry weight were favourably influenced by drip fertigation. All the drip irrigation levels have recorded high root dry weight with less root length as compared to surface irrigation. Hagin et al. [22] reported that drip 
irrigation generates a restricted root system requiring frequent nutrient supply that may be satisfied by applying fertilizer through irrigation water. Improving crop yield and quality and reducing loss of nutrients by way of leaching below the rooting zone may be achieved by managing fertilizer concentrations in irrigation water, based on the crop requirements. Major root activity was observed in the wetted volume of soil Haynes et al. $[65,66]$. Observed enhanced root spread and root dry mass of maize under drip fertigation practices while rooting depth was more under surface irrigation method.

\section{Nutrient Requirement For Pulses}

The three major and primary nutrients required for the crop growth and productivity are Nitrogen, phosphorus and potassium. Small quantity of nitrogen is very important during early stage of seedling growth. Phosphorus is important for energy storage and transfer and also essential for vigorous growth and development of seeds. Especially in grain crops, it enhances crop maturity and quality. Potassium maintains water balance and strength of the stalk. In addition, it also promotes energy generation which is essential for translocation of nutrients in the plant, $\mathrm{N}$ uptake and protein synthesis. Crops that suffer with $\mathrm{K}$ deficiency lead to low total $\mathrm{N}$ uptake, yield and protein. Proper inoculants and sufficient amounts of $\mathrm{P}, \mathrm{K}$, sulphur and micronutrients are available in the soil, legumes can fix their own nitrogen. $\mathrm{N}$ uptake was maximum during branching and early bud formation Malhi et al. [67]. During early growing period, availability of $\mathrm{P}$ and $\mathrm{K}$ is critical not only for direct incorporation, but to ensure early $\mathrm{N}$ fixation. The nutrient uptake by pigeonpea is mainly depends on yield, which in turn vary with season, variety, soil, nutrient status and cultural practices followed in particular region. During early stage of Pigeonpea growth, it takes up relatively small amounts of nutrients, but as it grows and develops, the daily rate of nutrient uptake increases and it requires an adequate supply of nutrients at each growth stage for optimum yield. Substantial quantity of nutrients removal from the soil by high yielding long duration pigeonpea, this should be taken into consideration in an overall nutrient management plan.

\section{Drip Fertigation}

Fertigation is the process where application of fertilizers was done through irrigation water. By definition, fertigation is the precise application of water soluble fertilizers through sprinkler and drip irrigation systems Billsegars et al. [68]. Considerable saving of fertilizers can be achieved when the fertilizers were applied along with water through drip irrigation system. Apart from yield increase there was saving of water compared to surface method of irrigation. It helps to achieve higher fertilizer and water use efficiency. The risk of crop damage in many crops due to high water table coupled with heavy rains can be minimized by drip fertigation. It allows nutrient supply directly into root zone during critical periods of nutrient demand by the crop Kozhushka et al. [69]. Drip fertigation also provides efficient fertilizer delivery system and reduce overall fertilizer application rate and minimize the adverse environmental impact Hartz et al. [70]. The increasing area of drip irrigated crops facilitates an excellent opportunity to explore complete and balanced plant nutrient programs that have the potential to improve plant health and increase yields. Improved efficiency of fertilizer recovery can be achieved by fertigation Miller et al. [71-72], reduction fertilizer losses due to leaching control of nutrient concentration in soil solution flexibility in timing of fertilizer application in relation to crop demand based on development and physiological stage of crops. Besides, fertigation reduces soil solution salinity due to fertilizers Papadopoulos [17], thereby improves soil solution conditions particularly for salt sensitive crops, and conserves labour and energy.

Advantages of application of fertilizers through the irrigation system [73]:

a) According to crop requirements, nutrients can be applied at any time during the season

b) Movement of mobile nutrient like Nitrogen can be regulated through amount of water applied in the soil profile by placement

c) Applied nutrients are readily available for rapid crop uptake

d) Uniform application of nutrients over the field

e) Minimal crop damage during fertilizer application

With the possible exception of foliar sprays, the existing macronutrients (nitrogen, phosphorus, potassium, sulphur, calcium and magnesium) nutrient deficiency can be corrected in quickest ways through fertigation. There is a possibility of plant foliage burnt, if the macronutrients are applied at high rates in foliar sprays. Fertigation provides improved efficiency of irrigation, nutrient use and reduces cost of application. It also improves plant growth, nutrient uptake and reduces nutrient losses $[73,74]$ reported that through fertigation fertilizer saving and increase in yield of tomato. Fertigation saves the fertilizer to the tune of 25-50 per cent Haynes et al. [75]. In modern irrigated agriculture, fertigation became an attractive technology as it increase in yield and quality together with the improved water and fertilizer efficiency Papadopoulos et al. $[17,76]$ reported that significant higher tomato fruit yield (107.3 t ha-1) was obtained by fertigation which was 42.3 per cent higher than band placement. In general, frequent nutrient applications have improved the fertilizer-use efficiency and crop response to fertilizer application through drip irrigation Malik et al. [77]. Nutrient supply through fertigation to crops is mainly depends upon their concentration in irrigation water, plant nutrient uptake, rate of evapotranspiration and reactions such as precipitation or fixation. According to crop requirements, optimization of nutrient and water supply for increasing crop yield and quality and also reducing leaching losses below the rooting zone are achieved by managing fertilizer concentrations in measured quantities of irrigation water Hagin et al. [22]. Fertigation improved the overall root activity, mobility of nutritive elements and their uptake was improved, as well as reduction in surface and ground water contamination. The fertigation technology is mainly used for $\mathrm{N}$ and $\mathrm{K}$ fertilizers, as $\mathrm{P}$ is always applied as basal [78]. Through fertigation, yields of maize 
(7.9 t ha-1) and wheat (6.4 t ha-1) is possible to increase the crop productivity of sandy soils of low fertility [73]. Drip irrigation is an efficient method for fertigation, as both time and rate of nutrients will be well controlled to meet the requirements of a crop at each physiological stage of growth Bar Yosef et al. $[79,80]$ stated that fertigation is the most efficient and effective method of fertilizer application for all crops.

This results in reducing leaching and volatilization losses, improves the $\mathrm{N}$ utilization efficiency and minimizes ground water contamination Papadopoulos et al. [17]. As an additional benefit, applying $\mathrm{N}$ fertilizer along with the irrigation water is a more suitable and less expensive method compared to the traditional soil application methods. Fertigation allows us to supply nutrients directly to the active roots surface where the plants can readily uptake for the further process Sivanappan et al. $[42,79]$ stated that drip fertigation system delivers water and nutrients at a proper rate, duration and frequency, so as to maximize water and nutrient uptake by individual plant, while reducing leaching loss of nutrients and chemicals from the root zone. Fertigation has an advantage that the nutrients are applied in solution form near the root zone hence, they are readily available to the plants. Apart from this, the quantity of nutrients delivered can be easily managed to meet the crop needs. Kozhushka et al. [69] reported that fertigation allows nutrient placement directly into root zone of crop during critical periods of nutrient requirement by crops. Drip fertigation provides an efficient method of fertilizer delivery and if properly managed, reduce overall fertilizer application rate and minimize the adverse environmental impact Hartz et al. [70].

\section{Economics of Drip Fertigation}

Fertigation enable farmers to reduce the cost of cultivation and to increase the economic product as high as possible. Hence, attaining maximum benefits from each unit of water and nutrient applied to crop are important. For successful adoption of fertigation, application of straight and water-soluble fertilizer through drip would be economically viable. Narkhede et al. [81] reported in cotton that drip fertigation with 1.5 litre day- 1 plant- 1 recorded maximum gross returns $(16,085$ ha- 1$)$, net returns $(8,159$ ha-1) and returns per rupee invested (2.02) as compared to low level of drip fertigation at 0.5 litre day- 1 plant- 1 . The B: $\mathrm{C}$ ratio was much higher in tomato under drip irrigation, the water saved can be utilized to cover additional area of the same crop Hugar et al. [82]. Application of 80 per cent of normal fertilizers in the form of DAP, urea and MOP at bimonthly intervals was economical and effective in realizing higher yields and returns.

Water-soluble fertilizers were found to be better source for fertigation than the normal fertilizers as they resulted in less clogging Venkateshamurthy et al. [83]. Many scientists reported that additional benefit of WSF over normal fertilizers in fertigation was masked due to high cost of WSF in cotton Shinde et al. $[84,85]$ in sugarcane observed that scheduling of irrigation by weekly surface irrigation at 1.0 Epan recorded higher B: C ratio (5.8) which was on par with drip irrigation at 0.8 Epan (5.2) over 0.4 and 0.6 Epan by drip (3.9 and 4.3, respectively) in sweet corn in red sandy loam soil.
Veeraputhiran et al. [86] reported that drip fertigation with $120 \mathrm{~kg}$ $\mathrm{N}$ ha-1 registered higher net income of ` 48,886 ha-1 as compared to furrow irrigation. He also reported that even though higher cost was involved for drip unit, benefit cost ratio for drip fertigation was the lowest when compared to furrow irrigation. Ramesh et al. [13] stated that the highest net return of `30,105 ha-1 and B:C ratio of 2.75 were registered under drip irrigation as compared to furrow irrigation (21,750 ha-1 and 2.04, respectively).

Sampathkumar et al. [87] reported that drip irrigation at 100 per cent PE once in 3 days interval with coir pith mulching registered higher net profit of ' 30939 ha-1 and B:C ratio of 2.34 than drip irrigation at 60 per cent PE once in 7 days. Patil et al. [88] stated that paired row planting $(60 / 120 \mathrm{~cm} \times 60 \mathrm{~cm})$ was better than single row planting $(90 \times 60 \mathrm{~cm})$ with considerable saving of drip system cost towards laterals. Drip fertigation with 100 per cent RDF recorded higher $B$ : C ratio (1.79) followed by drip fertigation with 125 per cent RDF (1.77). Drip irrigation in cauliflower and hybrid chilli sequence gave a net return of 1,23,679 ha- 1 against 35,418 ha-1 in check basin method of irrigation Singh et al. [89] Drip fertigation of pigeonpea at branching and pod development stage along with NK@ 10:10 kg ha-1 in 5-10 splits gave additional net monitory return of 9000 ha-1 annum-1 Praharaj et al. [90-94].

\section{Conclusion}

From the above review, it is clearly understood that drip irrigation requires less irrigation water as the irrigation efficiency is increased compared to conventional irrigation method and also ensure uniform distribution of water and nutrients to the crops. It also increases the fertilizer use efficiency; in turn it leads to increase in yield and economic returns to the farming community [95-97]. High yield and the quality of produce is mainly depends upon the correct combination of water and nutrients. Fertigation has the potential to ensure that the right combination of water and nutrients is available at the root zone, results in higher yield and quality of the product.

\section{References}

1. Solaimalai A, M Baskar, A Sadasakthi, K Subburamu (2005) Fertigation in high value crops- A review. Agric Rev 26(1): 1-13.

2. Saxena MC, DS Yadav (1975) Multiple cropping with short duration pulses. Indian J Genetics \& Plant Breeding 35: 194-208.

3. Agarwal MC, AS Dhindwal, ASCS Jaiswal, A Prabhakar, MS Aujla (1997) Status of research on agricultural water management of Northeren Region. AICRP on Water Management, Directorate of Water Management Research (ICAR), Patna p. 138.

4. Tomar RS, MV Kanzaria, VK Jain (2001) Response of chickpea to potassium in a calcareous soil. J Potassium Res 17: 98-100.

5. Gajera MS, RPS Ahlawat (2006) Optimization of irrigation and evaluation of consumptive water use efficiency for rabi pigeonpea (Cajanus cajan (L) Millsp). Legume Res 29(2): 140-142.

6. Pramod G (2007) Response of Pigeonpea (Cajanus cajan (L.) Millsp.) genotypes to planting geometry under different protective irrigation. Karnataka J Agric Sci 2(4).

7. Duraisamy VK, P Manickasundaram (2008) Agronomic management for perennial redgram through irrigation and mulching. Madras Agric J 95(1-6): 205-207. 
8. Mula MG, KB Saxena, A Rathore, RV Kumar (2010) Response to spacing and irrigation in medium-duration CMS line of pigeonpea. J Food Legumes 23 (3\&4): 186-190.

9. Thanki JD, RK Solanki (2010) Response of rabi pigeonpea (Cajanus cajan (L.) Millsp) to moisture regimes and fertilizer management with and without FYM under south Gujarat condition. Crop Res 39(1, 2\&3): 39 42.

10. Becker TW, H Moria, HP Fock (1986) Evidence for the participation of dissimilatory process in maintaining high carbon fluxes through the photosynthetic carbon reduction and oxidation cycles in water stress Phaseolus leaves. Photosynthetica 20: 153-157.

11. Arkin GF, WD Rosenthal, WR Jordan (1983) A sorghum leaf area model. ASAE Technical Paper 83-2098. American Society of Agricultural Engineers, St. Joseph, MI.

12. De Lucad'Oro GM, VS Trippi (1987) Effect of stress conditions induced by temperature, water and rain on senescence development. Plant and Cell Physiology 28(8): 1389-1396.

13. Mukherjee D, Ramesh Kumar (2005) Water stress induced physiological and biochemical changes in different plant parts of pigeonpea. Bulletin of the National Institute of Ecology 15: 191-199.

14. Porter A Monty, Bidlack E James (2011) Morphology, biomass and vessel diameter of pigeonpea subjected to water stress. Communications in Soil Science and Plant Analysis 42: 2334-2343.

15. Bucks DA, S Davis (1986) Historical development. In: Proc. Trickle Irrigation for crop production, design, operation and management. Nakayama FS, DA Bucks (Eds.). Elsevier Sci 1-21.

16. Phene CJ, JL Fouss, DC Sanders (1979) Water-nutrient-herbicide management of potatoes with trickle irrigation. Am Potato J 56(1): $51-$ 59.

17. Papadopoulos I (1992) Fertigation of vegetables in plastic-houses: Present situation and future prospects. Acta Hort 323: 151-174.

18. Patel RS, PG Patel, JC Patel, MM Patel (2006) Effect of irrigation and nitrogen on growth and yield of brinjal under drip system. J Maharashtra Agric Univ 31(2): 173-175.

19. Ahluwalia MS, Bladev Singh, BS Gill (1993) Drip irrigation system-its hydraulic performance and influence on tomato and cauliflower crops. J Water Management: 1(1): 6-9.

20. Nakayama FS, DS Bucks (1991) Water quality in drip/trickle irrigationA review. Irrig Sci 12(4): 187-192.

21. Martin GC, L Ferguson, VS Palito (1994) Flowering, pollination, fruiting, alternate bearing and abscission. In: Ferguson L, GC Sibbett, GC Martin (Eds.), Olive Production Manual, No. 3354. Division of Agriculture and Natural Resources, University of California, California, USA.

22. Hagin J, Anat Lowengart (1996) Fertigation for minimizing environmental pollution by fertilizers. Fert Res 43(1-3): 5-7.

23. Locascio SJ, SM Olson, FM Rhoads (1989) Water quantity and time of $\mathrm{N}$ and $\mathrm{K}$ application for trickle-irrigated tomatoes. J Amer Soc Hort Sci 114: 265-268.

24. Bafna AM, SY Daftardar, KK Khade, PV Patel, RS Dhotre (1993) Utilization of nitrogen and water by tomato under drip irrigation system. Water Manag 1(1): 1-5.

25. Sampathkumar T, S Krishnasamy, K Ramesh, K Shanmugasundaram (2006) Effect of drip and surface irrigation methods with rice straw mulch on productivity and water use efficiency of summer cotton. Crop Res 32(2): 141-144.

26. Hebbar SS, BK Ramachandrappa, HV Nanjappa, M Prabhakar (2004) Studies on NPK drip fertigation in field grown tomato (Lycopersicon esculentum Mill) Europ J Agron 21(1): 117-127.

27. Abdullah Oktem (2008) Effects of deficit irrigation on some yield characteristics of sweet corn. Bangladesh J Bot 37(2): 127-131.
28. Gupta AJ, M Feza Ahmad, FN Bhat (2010) Studies on yield, quality, water and fertilizer use efficiency of capsicum under drip irrigation and fertigation. Indian J Hort 67(2): 213-218.

29. Yazar A, SM Sezen, B Gencel (2002) Drip irrigation of corn in the South East Anatolia Project (GAP) area in turkey. Irrig and Drain 51(4): 293 300 .

30. Nazirbay I, SR Evett, Y Esanbekov, B Kamilov (2005) Water use of maize for two irrigation methods and two scheduling methods (abstract). Agronomy Abstract, ASA-CSSA-SSSA, Annual Meeting, Salt Lake City, Utah, India.

31. Anil Kumar, S Mugalkhod (2005) Response of baby corn to planting methods and irrigation schedules under drip. M.Sc. (Ag.) Thesis, University of Agricultural Sciences, Dharwad, India.

32. Rani S (2006) Agronomic options to maximize the yield of baby corn (Zea mays L.) in Periyar Vaigai Command area. M.Sc. (Ag.) Thesis, TNAU, Coimbatore, India.

33. Anil Jain (2010) Revolution of drip irrigation in Maharastra-A success story. Maharastra Economic Development Council, Monthly Economic Digest. May issue, pp. 31-33.

34. RamuluV, MD Reddy, AM Rao (2010) Response of rabi maize to irrigation schedules and fertigation levels Agric Sci Digest 30(2): 104-106.

35. Mahalakshmi K, K Avil kumar, MD Reddy, M Uma Devi (2011) Response of rabi pigeonpea [Cajanus cajan (L.)] to different levels of drip irrigation. J Res ANGRAU 39(4): 101-103.

36. Malik RS, K Kumar (1998) Effect of plant spacing and nitrogen fertilizer application on the yield and quality of tomato under drip irrigation. Agrl Sci Digest 18(2): 76-78.

37. Thompson TL, TA Doerge, RE Godin (2000) Nitrogen and water interactions in subsurface drip-irrigated cauliflower: I. Plant Response. Soil Sci Soc Am J 64: 406-411.

38. Mahendran S, J Stephen, AC Arun, P Prabakaran, R Raja (2005) Drip fertigation- potential technology for sugarcane yield maximization. Proc. Nation. Sem. Relevance of Microirrigation in Sugarcane, 9-10 February 2005, VSI Pune, Maharashtra, India, pp. 170-178.

39. Manish Kumar, RS Tripathi, GK Shrivastava (2001) Quality and yield of winter maize as affected by varying genotypes, nitrogen levels and irrigation schedules. Madras Agric J 88(10-12): 693-696.

40. Sunder Singh SD (2001) Effect of irrigation regimes and nitrogen levels on growth yield and quality of baby corn. Madras Agric J 88(9): 367-370.

41. Earl KD, WA Jury (1977) Water movement in bare and cropped soil under isolated trickle emitters: II. Analysis of cropped soil experiments. Soil Sci Soc Am J 41: 856-86.

42. Sivanappan RK, O Padmakumari, V Kumar (1987) Drip Irrigation. Keerthi Publishing House, Coimbatore, India, pp. 75-80.

43. Goel AK, RK Gupta, Rajinder Kumar (1993) Effect of drip discharge rate on moisture distribution pattern J Water Manage 1(1): 50-51.

44. Khepar SD, PK Neog, MP Kaushal (1983) Moisture and salt distribution pattern under drip irrigation. In: 2nd National seminar on drip irrigation. Coimbatore. pp. 76-85.

45. Patil TT (1999) Fertigation-A key to boost Indian agri exports. Agro India. October, p. 15-18.

46. Li J, J Zhang, M Rao (2004) Wetting patterns and N distributions as affected by fertigation schemes from a surface point source. Agr Water Manage 67: 89-104.

47. Amin MSM, AIM Ekhmaj (2006) DIPAC-Drip irrigation water distribution pattern calculator. In: $7^{\text {th }}$ International Micro Irrigation Congress, p. 10 16.

48. Suresh Kumar P (2000) Performance evaluation of drip fertigation system with water soluble fertilizers on water, fertilizer use and yield in hybrid capsicum. M.Sc. (Ag.) Thesis, TNAU, Coimbatore, India. 
49. Veeraputhiran R (2000) Effect of drip irrigation and fertigation on growth and yield of hybrid cotton. Ph. D. Thesis, TNAU, Coimbatore, India

50. Prashant Shrivastava, Govind Singh Rajput and Siddarth Nayak (2011) Soil moisture distribution as influenced by drip irrigation supply and planting pattern in heavy soils of Madhya Pradesh. J Agri Tec 7(4): 11771186.

51. Stanhill G, Y Vaadia (1967) Factors affecting plant response to soil water. In: Irrigation of Agricultural lands. Agronomy No. 11, Am Soc Agron pp. 446-457.

52. Follett RF, RR Allmaras, GA Reichman (1974) Distribution of corn roots in sandy soil with a declining water table. Agron J 66(2): 288-292.

53. Wiegand CL, ER Lemon (1958) A field study of some plant soil relations in aeration. Soil Sci Soc Am Proc 22(3): 216-221.

54. Brandt A, E Bresler, N Diner, I Ben Asher, J Heller, D Goldberg (1971) Infiltration from a trickle source. I. Mathematical models. Soil Sci Soc Am Proc 35(5): 675-682.

55. Lemon ER, AE Erickson (1955) Principle of the platinum micro-electrode as a method of characterizing soil aeration. Soil Sci 79: 383-392.

56. Silberbush M, B Gornat, D Goldberg (1979) Effect of irrigation from a point source (trickling) on oxygen flux and on root extension in the soil. Plant and Soil 52(4): 507-514.

57. Hudson JP (1962) Characteristics of the trickle irrigation system. Adv Hort Sci Appl 3: 264-272.

58. Stevens RM, T Douglas (1994) Distribution of grapevine roots and salt under drip and full-ground cover microjet irrigation systems. Irrig Sci 15(4): 147-152.

59. Clothier BE, KRJ Smettem, P Rahardjo (1990) Sprinkler irrigation, roots and the uptake of water. In field-scale water and solute flux in soils. Monte Verita. Birkhauser Verlag Basel pp. 101-108.

60. Clothier BE, KRJ Smettem, P Rahardjo (1990) Sprinkler irrigation, roots and the uptake of water. In field-scale water and solute flux in soils. Monte Verita. Birkhauser Verlag Basel pp. 101-108.

61. Sharp RE, WJ Davis (1985) Root growth and water uptake by maize plants in drying soil. J Exp Bot 36: 1441-1456.

62. Clausnitzer V, JW Hopmans (1994) Simultaneous modeling of transient three-dimensional root growth and soil water flow. Plant and Soil 164(2): 299-314

63. Oliveira MRG, AM Calado, CAM Portas (1996) Tomato root distribution under drip irrigation. J. Amer. Soc Hort Sci 121(4): 644-648.

64. Vanangamudi K, KS Suramanian, M Bhaskaran (1990) Influence of irrigation and nitrogen on the yield and quality of chilli fruit and seed Seed Res 18 (2): 114-116.

65. Haynes RJ (1990) Movement and transformation of fertigated nitrogen below trickle emitters and their effects on $\mathrm{pH}$ in the wetted soil volume. Fert Res 23(2): 105-112.

66. Anitta Fanish S, Purushothaman Muthukrishnan, Pachamuthu Ayyadurai (2013) Root characters of maize as influenced by drip fertigation levels. American J Plant Sci 4(2): 340-348.

67. Malhi SS, AM Johnston, JJ Schoenau, ZH Wang, CL Vera (2007) Seasonal biomass acumulation and nutrient uptake of $\mathrm{P}$ and Lentil on a black chernozem soil in Saskatchewan. J Plant Nutr 30(5): 721-737.

68. Billsegars (2003) Fertigation in IMC Global (Eds.). Efficient fertilizer use: Manual, $4^{\text {th }}$ Edition. http: // www.agcentral.com /imcdemo/10 fertigation. html.

69. Kozhushka LF, Romanets V (1994) Ecological and economical efficiency of mineral fertilizer application as a component of irrigation water. In: $17^{\text {th }}$ ICID European Reg Conf Irrig Drain 16-22, pp. 209-213.
70. Hartz TK, GJ Hochmuth (1996) Fertility management of drip irrigated vegetables. Hort Tech 6(3): 168.

71. Miller RJ, DE Rolston, RS Raushkolb, DW Wolf (1981) Labelled nitrogen uptake by drip-irrigated tomatoes. Agron J 73(2): 265-270.

72. Phene CJ, DW Beale (1976) High-frequency irrigation for water and nutrient management in humid region. Soil Sci Soc Am J 40(3): 430-436.

73. FAO (2005) Fertilizer use by crop in Egypt. Food and Agriculture Organization of the United Nations. Rome.

74. Bar Yosef, BB Sagiv (1982) Response of tomatoes to N and water applied via trickle irrigation system. Agron J 74: 633-637.

75. Haynes RJ (1985) Principles of fertilizer use for trickle irrigated crops. Ferti Res 6(3): 235-255.

76. Bafna AM, SY Daftardar, KK Khade, PV Patel, RS Dhotre (1993) Utilization of nitrogen and water by tomato under drip irrigation system. Water Manag 1(1): 1-5.

77. Malik RS, K Kumar, AR Bhandari (1994) Effect of urea application through drip irrigation system on nitrate distribution in loamy sand soils and pea yield. J Indian Soc Soil Sci 42(1): 6-10.

78. Taha MH (1999) Chemical fertilizers and irrigation system in Egypt. In: Proceedings of the FAO Regional Workshop on Guidelines for Efficient Fertilizers Use through Irrigation. Cairo, p. 14-16.

79. Bar Yosef, BB Sagiv (1982) Response of tomatoes to N and water applied via trickle irrigation system. Agron J 74: 633-637.

80. Feigin.

81. Gardenas AI,JW Hopman, BR Hanson, J Simunek (2005) Two-dimensional modeling of nitrate leaching for various fertigation scenarios under micro-irrigation. Agric. Water Management 74 (3): 219-242.

82. Narkhede WN, GM Bharad, SK Kohale (1996) Effect of plant density and drip irrigation on premonsoon cotton (Gossypium hirsutum L.) Indian J Agron 4 (1): 127-131.

83. Hugar LB (1996) In: Proc. All India Seminar on Modern Irrigation Technologies, Bangalore, June 26-27, pp. 293-297.

84. Venkateshamurthy P (1997) Studies on fertigation in Bangalore blue grapes- comparison of sources and levels of nutrients. Ph.D. (Hort.) Thesis, Univ, Agric Sci Bangalore.

85. Bhoi PG, DD Pawar, BS Raskar, AR Bangar, SH Shinde (2000) Effect of water soluble fertilizer through drip on the growth, yield and quality of suru sugarcane. In: proc. International conference on micro and sprinkler irrigation system, February 8-10, 2000, Jalgaon, Maharashtra, Indua, p. 86.

86. Viswanatha GB, BK Ramachandrappa, HV Nanjappa (2000) Effect of drip irrigation and method of planting on root and shoot biomass. Tasseling, silking interval, yield and economics of sweet corn (Zea mays Cv. Saccharata). Mysore J of Agric Sci 34(2): 134-141.

87. Veeraputhiran R (2000) Effect of drip irrigation and fertigation on growth and yield of hybrid cotton. Ph. D. Thesis, TNAU, Coimbatore, India.

88. Sampathkumar T (2003) Evaluation of drip and surface irrigation methods with rice straw mulching in cotton. M.Sc Thesis submitted to the Department of Agronomy, Agricultural College and Research Institute, TNAU, Madurai, Tamil Nadu, India.

89. Patil VC, HC Halemani, GK Girijesh, CP Chandrasekar, CM Kalibhavi, et al. (2004) Effect of drip and furrow irrigation on yield and quality of cotton. In: Proc. of International Symposium on Strategies for sustainable cotton production- A global vision, 23-25 $5^{\text {th }}$ November.

90. Ahluwalia MS, Bladev Singh, BS Gill (1993) Drip irrigation system-its hydraulic performance and influence on tomato and cauliflower crops. J. Water Management: 1(1): 6-9. 
91. Praharaj CS, Narendra Kumar (2011) Drip-fertigation in pigeonpea Indian Institute of Pulses Research. Pulses Newsletter: April- June. pp 5.

92. Feigin A, J Letey, WM Jarrell (1982) N utilization efficiency by drip irrigated celery receiving preplant or water applied $\mathrm{N}$ fertilizer. Agron J 74: 978-983.

93. Goldberg F, B Gornat, Y Bar (1971) The distribution of roots, water and minerals, as a result of trickle irrigation. J Amer Soc Hort Sci 96: 645648.

94. Haynes RJ (1985) Principles of fertilizer use for trickle irrigated crops. Ferti Res 6(3): 235-255.

95. Miller RJ, DE Rolston, RS Raushkolb, DW Wolf (1981) Labelled nitrogen uptake by drip-irrigated tomatoes. Agron J 73(2): 265-270.

\section{ISSN: 2574-1241}

DOI: 10.26717/BJSTR.2018.11.002110

M Uma Maheswari. Biomed J Sci \& Tech Res

CC (P) This work is licensed under Creative

Submission Link: https://biomedres.us/submit-manuscript.php
96. Ramesh K (2003) Impact of irrigation regimes, irrigation frequencies and coirpith mulching on drip irrigated summer cotton SVPR-2. M.Sc. (Ag.) Thesis, Department of Agronomy, Agricultural College and Research Institute, Madurai, TNAU, Tamil Nadu, India.

97. Singh KG, Gulshan Mahajan, Mukesh Siag (2005) Economic evaluation of drip irrigation system for sequential cropping of cauliflower and hybrid chilli. In: International Conference on Plasticulture and Precision Farming, November 17-21, 2005, New Delhi, India, p. 207.

98. Sukhdarshan Singh, Rakesh Sharda, PPS Lubana, Chetan Singla (2011) Economic evaluation of drip irrigation system in bell pepper (Capsicum annuum L. var. Grossum). Progressive Hort 43(2): 289-293.

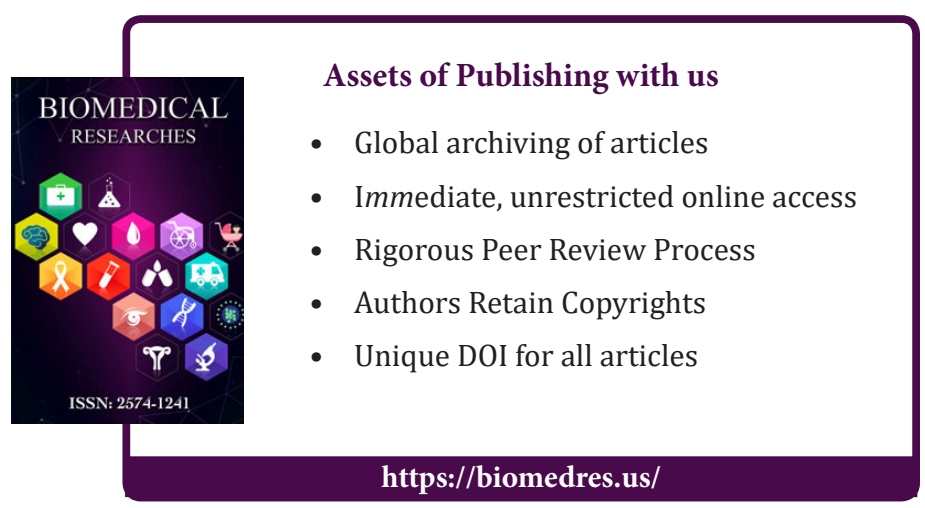

